\title{
THE EFFECTIVENESS OF TEACHING MODULE COMPUTER BASED DRILLING MODEL AND PRACTICE IN IMPROVING LEARNING ACHIEVEMENT OF INDONESIAN LANGUAGE
}

\author{
Padlurrahman, Muh. Jaelani Al-Pansori \\ Universitas Hamzanwadi, Nusa Tenggara Barat, Indonesia \\ Jalan TGKH. Muhammad Zainuddin Abdul Madjid No. 132 Pancor, Selong, Lombok Timur, NTB \\ Corresponding Author: jaelan_alpan@yahoo.com
}

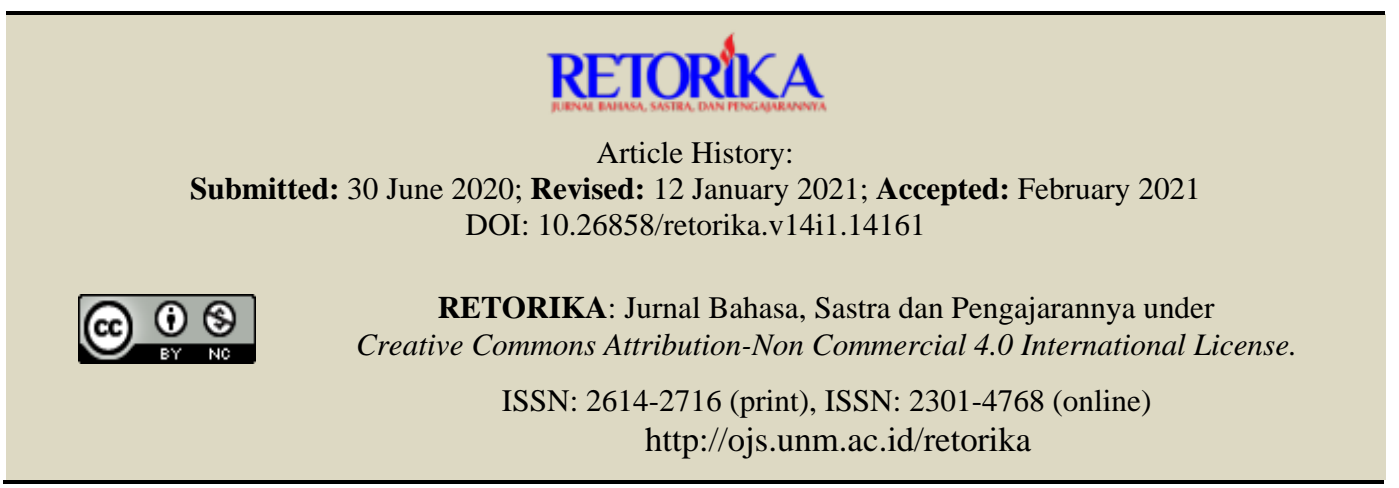

\begin{abstract}
This study aims to determine the effectiveness of the computer-assisted learning module for drill and practice model of Indonesian language learning in SMA/MA East Lombok District. This research includes development research through the stage of requirement analysis, limited sample testing and testing of action research settings. The research subject consists of teachers and SMA/ MA students in East Lombok district. Research Data is collected via questionnaire, observation sheets, tests, and interview guidelines. Data was analyzed using the component's anáolysis technique and continued with test-t analysis. The results showed that (1) th majority of teacher prepare the teaching materials independently than work collaboratively; (2) The result of learning Indonesian language through the use of a computer-assisted drill and practice based learning Module at each cycle increases, (3) There are differences in the results of Indonesian language learning between students who have been taught using a computer-assisted learning module drill and practice model with students who are taught without using a computer-assisted learning Module drill and practice model, and (4) students ' responses to learning modules developed and are in a good category.
\end{abstract}

Keywords: Computer-Assisted Learning, learning achivement, language teaching

Learning of Indonesian at schools is always seen by most students as the easiest subject. This view is based on the thoughts of students who think that Indonesian is only used as a tool in conveying their thoughts, opinions and desires, which according to them has been owned since birth and can speak. They consider that the ability to speak Indonesian can be owned by listening to and imitating other people. This view can indeed be justified, but more than that, teaching Indonesian properly and correctly can help students understand the universe and shape students' own behavior.

The results of the previous study show that Indonesian language teachers need efforts to improve Indonesian language skills through 
exercises and practice answering various questions easily and independently by the students themselves. In addition, teachers should have the ability to prepare better learning conditions so that they can improve learning achievement in Indonesian both during school and national exams. More than that, teachers and students can carry out a more meaningful learning process through practice and practice and are oriented towards student needs and current technological developments (Humaira, 2012; Inderasari, 2017). Thus, learning Indonesian, especially those involving four linguistic competencies, namely listening, speaking, reading, and writing requires a learning model that can accustom students to learning independently, efficiently, effectively, and fun. One of the learning models referred to is the computerassisted drill and practice model.

Theoretically, learning is a cultural process in the sense that learning becomes a vehicle for the delivery of the scientific culture and culture of national life to students as the next generation. In order for this to happen, Glasser (1993) states that there are 6 conditions that must be met for quality learning to occur, namely: (1) a warm and supportive classroom atmosphere; (2) students are only asked to do something useful; 3 ) students are always asked to perform the best they can do; (4) students are asked to assess and improve/ perfect their own work; (5) quality work always creates pleasure for everyone involved in it; and (6) quality work never damages.

One of the lessons known in this technological era is computer-assisted learning which is usually known as Computer-Assisted Instruction (CAI) or Computer-assisted Learning (CAI). This learning is a process designed to produce a specific learning interaction environment with the aim of providing learning facilities with software or other forms of computer applications (Jonassen, 1988; Wardani, 2007; Firmantika, 2014). Computer technology, whether in the form of hardware or software, usually has the following characteristics: (a) can be used randomly, besides linearly; (b) can be used in accordance with the wishes of the learner, in addition to the way as designed by the developer; (c) ideas are usually expressed abstractly by using words, symbols or graphics; (d) cognitive science principles applied during development; and (e) learning can be learnercentered with a high level of activity.
Based on the above opinion, it is concluded that Computer Assisted Learning is a system of delivering material through computers as a tool, where the material is stored in digital form and not in printed form.

The benefits of computer-based learning are (1) learners can adjust to their learning speed; (2) can train patiently (drill and practice); (3) can be used for independent study; (4) various kinds of sensing can be presented in the presentation; (5) can simulate; (6) learning can be presented in the form of a game so that it can generate motivation to learn; (7) problem solving skills can be developed; (8) can give praise to reinforce positive behavior; and (9) can assist classroom and school management (Woolfolk, 1988; Zamani, 2016; Bastani 2014; Saman, 2018). Computers and multimedia can be used in a variety of situations, among others (1) practicing what they have just studied in class; (2) leaning independently (tutorial); (3) building capacity to learn; (4) working collaboratively eith other students; (5) enhancing learning opportunities for gifted students, at al (Smaldino dan Russel, 2007:139). There are 5 forms of computerassisted learning that can be done in any field, namely tutorials, drill and practice, problem solving, simulations, and games (Santun, 2016; Ismanto, 2017; Nugroho, 2014).

The above five computer-assisted learning models, the one chosen in the development of Indonesian language learning Modules is the drill and practice model. Roblyer and Doering (2010: 79) state that the drill and practice model can provide students to work independently and receive direct feedback from others. Meanwhile Merrill \& Salisbury in Roblyer and Doering (2010: 79) states that this model can also meet the needs of students. This model provides a more concrete or real learning experience through the creation of imitation forms of experience that are closer to the actual atmosphere. In other languages, Roblyer and Doering (2010: 81) state that the benefits of the drill and practice model are (1) it can provide feedback to students; (2) creating students' learning motivation, and (3) students needing less time and teacher time is also more efficient (saving teacher time). Based on this concept, drill and practice learning is considered very appropriate for subject matter that trains students to have proficiency in a skill or strengthen mastery of a certain concept, including learning to write. Continuous practice 
and practice experienced by students can act as a stimulus that can shape behavior in the form of Indonesian language skills or abilities. Exercises and practices using Indonesian can provide a more concrete experience for the students themselves. The more so if students can do it independently without the intervention of others. Willingham, quoted by Mandy Stem (2012), found that the form of classroom instruction and the conditions of students who feel that what they are learning is irrelevant to their lives will have low attitudes and motivation at school and will have an impact on their academic.

In addition, Bruner (1966) revealed that there are 3 main levels of learning mode, namely: enactive (direct experience), iconic (pictorial experience or image), and symbolic (abstract experience). This means that the acquisition of knowledge and skills as well as changes in attitudes and behavior can occur because of the interaction between new experiences and experiences that have been experienced previously through the learning process. Then the knowledge and skills can be learned from pictures, photos, films or video recordings. Furthermore, at increasing the abstract, students can understand it from reading or listening and match it with the experience of seeing other people or examples.

Meanwhile, in developing a learning model, there are 5 elements that must be considered, namely: (1) Syntax, namely the steps or stages of implementing learning; (2) Social system, namely the atmosphere and norms that apply in learning; (3) The principle of reaction, which describes how the teacher should see, treat, and respond to students; (4) Support systems, namely all means, materials, tools or learning environments that support learning; (5) Instructional and nurturant effects, namely direct learning outcomes based on the targeted objectives and targeted external learning outcomes (Joice and Weil, 1980). These five elements were adapted in developing Indonesian language learning Modules.

\section{METHOD}

This research was development research (research and development) with the Borg \& Gall model using a waterfall flow. At the development stage, it includes the needs analysis stage, small group trials and field trials in the CAR setting and quasy experiment. The research subjects were high school/ MA students in East Lombok district. For the implementation of the ACTION RESEARCH setting trial, the subject was determined by considering the completeness of the learning facilities, especially the computer laboratory. While the trial was in a quasy experimental setting, each class was chosen randomly.

Try-out through setting ACTION RESE$\mathrm{ARCH}$ and quasy experiment was carried out in class X MA NW Pancor skills. Limited trials were conducted on 15 students and trials on a large sample were carried out through the CAR setting on 20 students in class X MA Skills NW Pancor. Meanwhile, the trial through the quasy experimental setting was carried out on students who were divided into 2 groups, namely the Experimental group with 22 people and the control group with 22 people.

The research data were collected through (1) tests of language skills in Indonesian covering aspects of listening, speaking, reading and writing, (2) questionnaire responses from teachers and students to learning Modules that have been developed, (3) observation sheets of learning implementation, and (4) interview guidelines.

The collected data were analyzed using descriptive statistics, whose conclusions were based on mean values and standard deviation. Data on teacher and student responses to the learning Module will be analyzed using descriptive statistics using 5 qualification levels as a conversion guide. Data on the results of students' language skills tests in the CAR setting will be analyzed descriptively and equipped with graphics. Meanwhile, the students' language skills test data in the experimental quasy setting will be analyzed using t-test analysis.

\section{FINDINGS AND DISCUSSION}

\section{Findings}

The tryout of Indonesian language learning Modules is carried out through limited sample trial settings, ACTION RESEARCH, and quasy experiments. The trial was carried out in 3 stages, namely: First Stage, a limited sample trial was conducted in 15 students of MA Keteranpilan NW Pancor in East Lombok district. The tryout results on a limited sample showed that, at each 
stage of the trial, there was a significant increase in learning outcomes. This increase in learning outcomes is the impact of using learning Modules and application of drill and practice models in the classroom. To illustrate the increase in learning outcomes above, the following is presented in graphical form.

\section{Figure 1. Post-Treatment Learning Achievement Improvement}

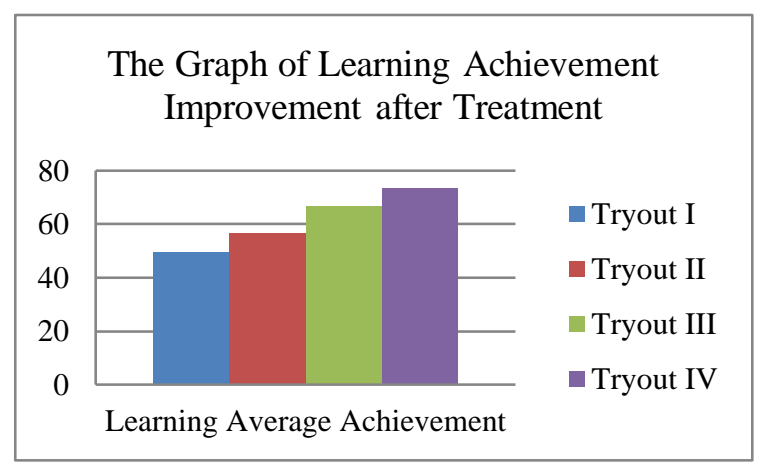

Meanwhile, student response data to the developed learning Module showed a high response to the categories of learning material, syllabus, lesson plans and learning scenarios, teaching materials, learning outcome instruments and the application of the drill and practice model used by the teacher, where the average student response was 133 . 80. These results indicate that the mean of 133.80 is in the high category. This shows that the response to the Indonesian language learning Module in SMA/ MA is in the Good category or is in the 133.7------ 42.1 range.

The second stage, Tests through the ACTION RESEARCH setting and quasy experiment. The test on the ACTION RESEARCH setting was carried out in 1 class, namely class X MA Skills NW Pancor with 20 students. The summary of the trial results can be described in the following table.

Table 1. Summary of Tryout Results

\begin{tabular}{clll}
\hline No. & Cycles & Average & \multicolumn{1}{c}{ Improvement } \\
\hline 1. & First (I) & 60.6 & 19.7 poin / $19,7 \%$ or \\
& & & $20 \%$ \\
\hline 2. & Second (II) & 80.3 & \\
\hline
\end{tabular}

Testing in this quasy experimental setting was carried out through 3 meetings in each group, namely the experimental and control groups. The number of students in each group is 22 people without changing the current class or group of students. The summary of the data obtained is as follows.

Table 2. The Average of Language Skills

\begin{tabular}{|l|c|c|c|c|c|c|c|c|}
\hline \multirow{2}{*}{ Groups } & \multicolumn{4}{|c|}{$\begin{array}{c}\text { The Average of Each } \\
\text { Linguistics Skills }\end{array}$} & $\begin{array}{c}\text { Mean } \\
\text { Score }\end{array}$ & $\begin{array}{c}\text { Standard } \\
\text { Deviasion }\end{array}$ & M & SD \\
\cline { 2 - 7 } & $\mathbf{1}$ & $\mathbf{2}$ & $\mathbf{3}$ & $\mathbf{4}$ & & & \\
\hline Experiment & 80 & 69 & 85 & 75 & 77 & 2,7 & \multirow{2}{*}{56.5} & 14.5 \\
\hline Control & 83 & 54 & 85 & 53 & 65 & 3,9 & & \\
\hline
\end{tabular}

The data above shows that the learning outcomes of students in the experimental group or groups that are taught using the drill and practice model of computer-assisted learning Modules are in the high or very good category, namely in the 71-----100 range. In the control group or the group that was taught without using the computer-assisted learning Module, the drill and practice model, was in the moderate or good enough category, which was in the range 42-----71.

The table above also shows that the mean of the four language skills, namely listening, speaking, reading, and writing skills also shows different categories. To describe the average student learning outcomes according to the following types of language skills can be seen in the graph.

Figure 2. The Mean of Students' Learning Achievement

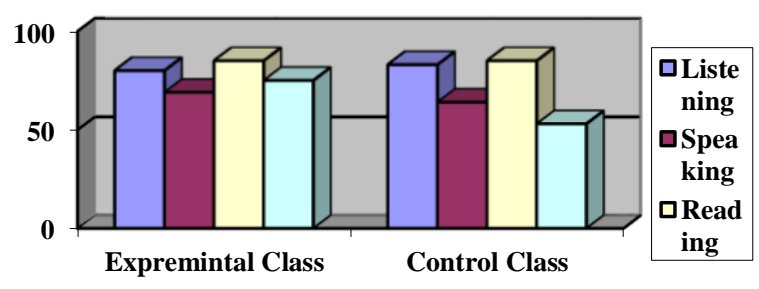


Figure 2 it shows that the linguistic abilities of students who are taught using the drill and practice model of computer-assisted learning Modules are different from those of students who are taught without using the computer-assisted learning Module, the drill and practice model. The graph of the difference in the average student learning outcomes in Indonesian in each group can be seen in the following graph.

Figure 3. The Difference of Average Learning Achievement

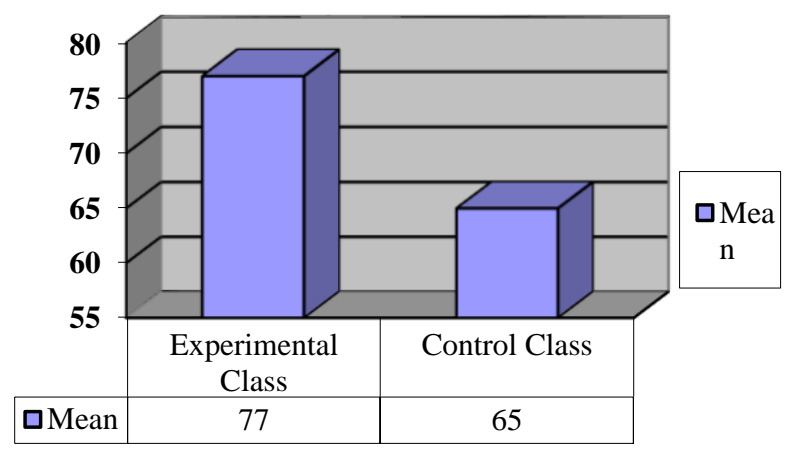

Figure 3 above shows that there is a difference in the mean learning outcomes of students who are taught using the drill and practice model of computer-assisted learning Modules and those not taught using the drill and practice model of computer-assisted learning Modules, which is 12 points. This difference shows that the mean learning outcomes of students who are taught using the drill and practice model of computer-assisted learning Modules are higher than the average learning outcomes of students who are taught without using the drill and practice model of computerassisted learning Modules or using previously available learning Modules.

To find out the above differences, it is necessary to test statistically through the $t$ test where the results of the calculation show that $\mathrm{t}=$ 3.53 and $t$ table $=1.68$ at the $95 \%$ significance level or $\mathrm{t}=3.53>\mathrm{t}$ table 1.68 so that the conclusion is obtained. that there are differences in learning outcomes in Indonesian subjects between students who are taught using the drill and practice model of computer-assisted learning Modules and students who are taught without using computer-assisted learning Modules in the drill and practice model or using learning Modules commonly used by teachers. This decision indicates that the learning Module developed can affect the learning outcomes of students' language skills.

\section{Discussion}

Generally, the results of the study indicate that the learning Module developed is a set of learning tools consisting of syllabus of Indonesian subjects, Learning Implementation Plans, Computer-based Learning Implementation Scenarios assisted with macromedia plash, Indonesian language teaching materials, and Indonesian language skills assessment instruments. This learning Module is used in Indonesian class X SMA/ MA as subjects or the equivalent. This Module is called the drill and practice model of computer-assisted learning Module.

Computer-assisted learning in the drill and practice model is preceded by the emergence of the opening animation "Computer Assisted Learning" which then enters the loading process and is followed by the sentence "Assalamu' alaikum Warohmatullohi Wabarokatuhu". After the end of the loading process, the next screen is computer-assisted learning animation and the topic "communication in life" as well as learning materials "Introduction to the structure of anecdotal text content and understanding of anecdotal text content". Along with the end of this animation, three menu options will appear, namely "User Guide", "About Program," and "Start". The "manual for use" menu contains instructions for using the PBK model of drill and practice, while the "about program" menu contains learning topics and learning objectives. Besides that, it also displays program objectives, competencies, time allocation, and information on the software used. As for the "start" menu, it functions to enter the computer-based learning program with the drill and practice model. In it, there are menu options, including: (1) Towards the next training material; (2) Looking at the score, provided that the correct answer is less than $80 \%$ of the completeness, then you have to repeat the exercise material and if the correct answer is above $80 \%$ then you can go to the next exercise material; and (3) Repeating the exercise material. It can be said that along with clicking the "start" button, the next display presents an animation around the material being discussed in the form of practice questions, the presentation of the 
question material is developed in accordance with the principles of learning the drill and practice model, question and answer responses, response assessment, giving feedback. response to student answers in the form of scores while the results of the exercise. While the final score can be found after completing all the practice questions that have been prepared. If the student meets the pass mark requirements for $80 \%$ of the correct answers from all the exercises that have been completed, the student can exit the program by clicking the exit button in the upper right corner. And if you have not met the pass limit of $80 \%$ then you have to repeat it again to answer the practice questions by clicking the "repeat" button. This drill and practice computer-assisted learning model can record all student performance, evaluate and provide feedback. The teacher has provided various types of practice questions to be completed by students according to the time allocation in the learning plan. This whole series of activities ended with a closing display and a thank you note.

The stages of learning in the drill and practice model presented above seem to be able to help students learn certain skills including student language skills. This model provides a more concrete or real learning experience through the creation of mock-ups of experiences that are closer to the actual atmosphere. In other languages, it is stated that the benefits of the drill and practice model are (1) it can provide feedback to students; (2) creating students' learning motivation, and (3) students needing less time and teacher time is also more efficient (saving teacher time). Drill and practice learning teaches subject matter that is arranged in sequence starting from the simplest to the most complex. In addition, in drill and practice learning it is necessary to explain the learning steps and the training/ practice mechanisms that will be carried out by students. Feedback by educators is very necessary in this model of learning and can be done as soon as possible if students experience errors/ difficulties in learning.

According to the results of the study, it was found that the average student learning outcomes increased from testing stage I to testing stage IV. The intended mean learning outcomes are seen from the student's ability to solve various questions on the learning outcome instruments that have been prepared by the teacher. This learning outcome instrument is an instrument developed by the teacher and oriented to drill and practice.
Some indications of improving student learning outcomes include: (1) the ability of students to listen to pieces of text that are read, (2) the ability of students to mention the structure of the content of anecdotal texts and expositions that have been read, (3) the ability of students to show the characteristics of anecdotal and exposition text language which has been read, (4) the ability of students to convey anecdotal texts and expositions orally by paying attention to pronunciation, conformity of content to the theme, and completeness of text elements, (5) the ability of students to understand and criticize the contents of anecdote and exposition text, (6) the ability of students to write anecdotal texts parts of the text include: abstraction, orientation, crisis, reaction, and coda, (7) students' ability to develop various types of exposition paragraph development, namely: Definition exposition, process exposition, classification exposition, illustrative exposition, comparative or contradictory exposition, and exposition report.

The increase in learning outcomes experienced by students above is not only a result of using the learning Module that has been developed. However, this increase is also an impact of students' responses to the drill and practice learning Module that has been developed. The average student response to the Indonesian language learning Module is in a good category. These results can be seen from the students' responses to (1) the learning material delivered by the teacher, (2) the syllabus used by the teacher in learning, (3) the lesson plan (RPP) used, (4) the teaching materials used by the teacher, (5) the assessment instru-ment. Learning outcomes used by the teacher, and (6) the application of the drill and practice model that has been developed. This response shows the positive attitude of students towards the learning Module developed.

The effectiveness of the drill and practice computer-assisted learning Module can also be proven from the test results through the ACTION RESEARCH setting. This can be seen from the increase in learning outcomes of Indonesian language subjects in students through the use of computer-assisted drill and practice-based learning modules in each cycle.

The increase in Indonesian learning outcomes above is due to several things, including: (1) the effort to train students' skills continuously, (2) the active participation of 
RETORIKA: Jurnal Bahasa, Sastra, dan Pengajarannya,

Vol. 14, No. 1, February 2021, pp. 40-48

students in com-pleting the given training tasks, (3) the existence of feedback that is given by the teacher directly to student skills, (4) the opportunity for students to improve learning outcomes through structured exercises.

The learning experiences described above indicate that learning Indonesian requires a more concrete learning experience through exercises and assignments or practice as well as the creation of copies that are closer to the actual atmosphere. These exercises are organized from the simplest to the most complex. The Indonesian language learning method should also refer to Bruner's view which also prioritizes direct experience in the form of practice or practice, experiences through pictures and reading or listening activities. It can be said that understanding and memory are two very important things in language learning. However, these two things must also be supported by appropriate materials and attitudes for learning. This is called a support strategy.

Supporting strategies are strategies that help maintain attention to appropriate materials and attitudes for learning (Tarigan, 2009; Adiwisastra, 2015; Kurniawan et al, 2019; Gulo, 2016). In the support strategy group there are aspects, including: handling attitudes, enthusiasm and motivation, planning and setting goals, social cooperation, creating opportunities for practice and training, cultural orientation, selfmanagement, and level structuring. Attitudes and motivation to learn language, the ability to plan and set goals in learning language, cooperation, opportunities for practice and practice, and habits in using language consciously are factors that support or support language learning itself.

Meanwhile, seen from the mean learning outcomes of students who were taught using the drill and practice model of computer-assisted learning Modules, it was higher than the mean learning outcomes of students who were taught without using the intended learning Module. This is due to the fact that learning using the computerassisted drill and practice-based learning Module emphasizes more on skill aspects. These findings suggest that language learning, including Indonesian, must be able to support one's mastery of a language used which is called competence and the real appearance shown directly by the learners themselves is called performance.
Kongskey itself defines learning as change that occurs through practice and practice.

The four language skills, the lowest mean learning outcomes occurred in the group of students who were taught without using the drill and practice model of computer assisted learning Modules, especially in writing skills. This is very different from the average writing skills of the group of students who were taught using the drill and practice computer-assisted learning Module. Meanwhile, the average reading ability of students in each group was stated to have the same average. This shows that the learning Module developed does not have a partial effect on learning outcomes on students' reading ability because there is no difference in the mean between the two groups. As for the aspect of speaking skills, the mean difference in learning outcomes is only 1 point. A striking difference occurs in the average listening ability of students between those taught using computer-assisted drill and practice-based learning Modules and those taught without using computer-assisted drill and practice-based learning Modules. In fact, the average listening ability was higher for students in the groups that were taught without using the computer-assisted learning Module, the drill and practice model.

The findings above reinforce the behavioristic learning theory pioneered by Thorndike, Pavlop, and Skinner which states that learning that occurs in each individual is behavior that can be observed. This observable behavior can be seen from the training and practice activities carried out directly by each student, either individually or in groups. Behavioral changes called attitudes, knowledge, and skills can be obtained through structured exercises and practices. Meanwhile, constructivist learning theory emphasizes that learning should be student-centered and that learning is the responsibility of the students. The teacher should always act as a facilitator and motivator during learning. These two theories are theories that underlie the need for a computer-assisted learning Module with a drill and practice model in learning that prioritizes aspects of skills including Indonesian language subjects in SMA/MA.

Behavioral changes called attitudes, knowledge, and skills can be obtained through structured exercises and practices. These exercises and practices for students should be 
activities carried out independently by each individual student. This is due to the fact that students' knowledge and understanding cannot be obtained passively but can only be obtained actively through individual experience in accordance with constructivist learning theory. This theory emphasizes that learning should be student-centered and that learning is the responsibility of the students. The teacher should always act as a facilitator and motivator during learning.

The two theories above are theories that underlie the need for a computer-assisted learning Module with a drill and practice model in learning that prioritizes aspects of skills including Indonesian language subjects in SMA/ MA. Another finding that supports the findings of this study is the conclusion made by Arwani (2012) that the active learning model and the drill method can improve learning outcomes.

The effectiveness of computer-assisted drill and practice-based learning Modules can also be seen from the difference in learning outcomes between students who are taught using the learning Module and those taught without using the intended learning Module. This difference can be seen from the positive and significant influence of the computer-assisted learning Module, the drill and practice model, which was developed on the learning outcomes of Indonesian subjects for students.

Learning Indonesian using computerassisted drill and practice-based learning Modules causes students to learn according to their respective abilities so that pressures from other people or the environment can be reduced. Students who have the ability to quickly solve simple learning problems can proceed to learning problems that are more difficult or complex through initial and advanced training.

Continuous practice and practice experienced by students through the developed learning Module can act as a stimulus that can shape behavior in the form of Indonesian

\section{REFERENCES}

Adiwisastra, M. F. (2015). Perancangan Game Kuis Interaktif sebagai Multimedia Pembelajaran Drill and Practice untuk Meningkatkan Hasil Belajar Siswa. Jurnal Informatika. 2 (1), 205211. language skills or abilities. Exercises and practices using Indonesian can provide a more concrete experience for the students themselves. The more so if students can do it independently without the intervention of others. Willingham, quoted by Mandy Stem (2012), found that the form of classroom instruction and the conditions of students who feel that what they are learning is irrelevant to their lives will have low attitudes and motivation at school and will have an impact on their academic achievement.

\section{CONCLUSION}

The drill and practice model of computerassisted learning Modules has been proven to improve the Indonesian language learning outcomes of SMA/ MA students in East Lombok district. The learning module in question consists of a set of learning tools which include syllabus, lesson plans, teaching materials, learning scenarios and assessment of learning outcomes. The effectiveness of learning modules developed in improving student learning outcomes can be seen from, (1) there is an increase in Indonesian learning outcomes through the use of computerassisted drill and practice-based learning modules in each cycle, (2) there are differences in Indonesian learning outcomes between students who are taught using modules Computer-assisted learning with the drill and practice model with students being taught without using this learning module (3) The average student response to the learning module is included in the good category.

Based on this conclusion, this developed learning Module needs to be used as a learning Module that is very effective in improving Indonesian language learning outcomes, especially in class X SMA/ MA in East Lombok district. However, in its use, it is necessary to have other supporting devices, namely the availability of computer media both in the classroom and in the computer laboratory.

Bastani, B., \& Pujiati S. (2014). Pengembangan Media Pembelajaran Kosakata Bahasa Inggris Berbantuan Komputer untuk Siswa SMP Kelas VII. Jurnal Ling Tera. 1 (1), 28-38.

Byrne, D. (1979). Teaching Writing Skill. London: Longman G. Limited. 
Firmantika, L., Mukminan M. (2014). Pengembangan Media Pembelajaran Berbantuan Komputer untuk Menanamkan Kesadaran Lingkungan bagi Siswa SMP. Harmonisasi Sosial Jurnal Pendidikan IPS. 1 (2), 155-156.

Gagne, M. \& Briggs, L. (1974). The Principle of Instructional Design. New York: Holt, Rinehart and Winston Inc.

Gulo, F. (2016). Aplikasi Pembelajaran Konversi Bilangan Menggunakan Metode Computer Assisted Instruction (CAI). Jurnal Riset Komputer (JURIKOM), 3 (6), 101-110.

Humaira, Desni, Fatmawati, \& Zulmiyetri. (2012). Pelaksanaan Pembelajaran Bahasa Indonesia bagi Anak Tunagrahita Ringan Kelas III di SLB Sabiluna Pariaman. JUPPEKhu (Jurnal Ilmiah Pendidikan Khusus), 1 (2), 95-109.

Inderasari, E., Tiya A. (2017). Pembelajaran Bahasa Indonesia pada Mahasiswa Asing dalam Program BIPA IAIN Surakarta. Jurnal Pendidikan Bahasa dan Sastra Indonesia, 6 (2), 6 15.

Ismanto, E. I., \& Eka P. C. (2017). Drill and Practice Model dalam Pembuatan Media Pembelajaran Interaktif Pembentukan Objek Primitif Sederhana Dua Dimensi. ALGORITMA: Jurnal Ilmu Komputer dan Informatika, 1 (1), 18-23.

Joice, B. \& Weil.M. (1996). Models of Teaching. $5^{\text {th }}$ Ed. Boston: Allyn and Bacon.

Jonassen. D.H. (1988). Instructional Design for Microcomputer Courseware. London: Lawrence Elbaum Associates Publichers.

Kemp, J.E. \& Dayton, D.K. (1985). Planning and Producing Instructional Media. New York: Harper \& Row Publishers Cambridge.

Krashen, S. D. (1984). Writing: Research, Theory, and Applycation. Oxford: Pergamon Institute.

Kurniawan, D. E., Afdhol D., Hilda W., Evaliata S., \& Rosida T. M. (2019). Smart Mathematics: a Kindergarten Student Learning Media Based on The Drill and Practice Model. Journal of Phisics. 1175, 1-6.

Nugroho, S. A., dkk. (2014). Penerapan Metode Drill and Practice Dilengkapi Modul untuk Meningkatkan Keaktifan dan Prestasi Belajar pada Materi Pokok Hidrolisis Garam Kelas XI IPA 5 SMA Negeri 7 Surakarta Tahun Pelajaran 2012/2013. Jurnal Pendidikan Kimia (JPK), 2 (4), 67-76.

Roblyer, M. D. \& Doering, A. H. (2010). Integrating Educational Technology into Teaching. New York: Pearson Education.

Saman. (2018). Penerapan Metode Drill and Practice untuk Meningkatkan Keaktifan dan Hasil Belajar Komputer Akuntansi Spreadsheet. Edudi-kara: Jurnal Pendidikan dan Pembelajaran, 3 (1), 43-50.

Sanatun, N.A. (2016). Implementasi Metode Drill and Practice Secara Kelompok untuk Peningkatan Prestasi Belajar, Unnes Physics Education Journal. 5 (3), 67-78.

Smaldino, S. E. \& Russel, J. D. (2008). Instructional Technology and Media for Learning. Upper Saddle River, New Jersey, Columbus, Ohio.

Stern, M. (2012). Evaluating and Promoting Positive School Attitude in Adolescents. New York: Springer.

Wardani S., L. Lindwati, S.B. W. Kusuma. (2007).The Development of Inquiry by Using AndroidSystem-Based Chemistry Board Game to Improve Learning Outcome and Critical Thinking Ability. Jurnal Pendidikan IPA Indonesia. 6 (2), 196-205.

Woolfolk, A.E. (1984). Educational Psycology for Teachers. Englewood cliffts. New Jersey: Prentice hall Inc.

Zamani, A. Z., Heru N. (2016). Pengembangan Media Pembelajaran Berbantuan Komputer untuk Meningkatkan Motivasi dan Hasil Belajar. Jurnal Pendidikan Matematika dan Sains, 4 (1), 89-100. 